\title{
REVIEW
}

\section{The effect of modifiable cardiovascular risk factors on cognitive aging}

Márta Germán-Sallól,2, Mónika Szaból,3, Zoltán Preg',,2, Enikő Nemes-Nagy", Dalma Bálint-Szentendrey ${ }^{1,2}$, Tünde Pál ${ }^{5}$

\begin{abstract}
Dementia represents a major health problem in elderly people. Several lifestyle-related and cardiovascular risk factors contribute to cognitive dysfunction, some of them can be counteracted, thus reducing the prevalence of dementia. Hypertension causes brain damage inducing micro- and macrovascular modifications, which can develop silently. Diabetes mellitus represents a major risk factor for cognitive decline due to hyperglycaemia, insulin resistance and chronic inflammation. Smoking increases the risk of dementia inducing vascular modifications and neurotoxicity. Midlife obesity is another risk factor for dementia, being associated with brain atrophy and having influence on other cardiovascular risk factors. Hypercholesterolemia, especially increased LDL-cholesterol might contribute to the development of dementia, but the results are controversial. Physical exercise has a protective effect on neuro-degenerative processes, especially the combination of aerobic and resistance exercise seems to have the best impact on cognitive function. These risk factors represent targets for intervention in preventing cognitive dysfunction, and screening can be helpful in the early diagnosis of this disease.
\end{abstract}

Keywords: cognitive dysfunction, dementia, modifiable risk factors, hypertension, type 2 diabetes.

Rezumat: Demența reprezintă o problemă majoră de sănătate la vârstnici. Există câțiva factori de risc cardiovascular legați de stilul de viață, care pot contribui la declinul funcțiilor cognitive. Unii dintre aceștia pot fi influențați prin măsuri de prevenție, fácând astfel posibilă reducerea prevalenței demenței. Hipertensiunea duce la apariția leziunilor cerebrale care, la rândul lor, provoacă modificări micro- și macrovasculare care se pot dezvolta silențios. Diabetul zaharat reprezintă un factor major de risc pentru declinul cognitiv, mecanismele implicate fiind reprezentate de hiperglicemie, creșterea rezistenței la insulină și inflamația cronică. Fumatul crește riscul de demență prin dezvoltarea modificărilor vasculare aterosclerotice și având efect de neurotoxicitate directă. Obezitatea prezentă la vârstă medie este un alt factor de risc pentru demență, fiind asociat cu atrofie cerebrală și având influență asupra altor factori de risc cardiovascular. Hipercolesterolemia, în special creșterea LDL colesterolului, ar putea contribui la dezvoltarea demenței, dar rezultatele studiilor sunt controversate. Exercițiul fizic are un efect protector asupra proceselor neuro-degenerative, în special combinația dintre exercițiile aerobe și de rezistență, care par să aibă cel mai benefic efect asupra funcțiilor cognitive. Acești factori de risc reprezintă obiective importante pentru prevenirea disfuncției cognitive, iar screening-ul declinului cognitiv și al demenței poate fi util în diagnosticarea precoce a acestei boli cu impact social important.

Cuvinte cheie: disfuncție cognitivă, demență, factori de risc modificabili, hipertensiune arterială, diabet zaharat tip 2.

' „George Emil Palade” University of Medicine, Pharmacy, Science and Technology, Targu Mures, Romania

${ }^{2}$ Department of Cardiovascular Rehabilitation, Emergency Clinical County Hospital, Targu Mures, Romania

${ }^{3}$ Department of Diabetes, Nutrition and Metabolic Diseases, Emergency Clinical County Hospital, Targu Mures, Romania

${ }^{4}$ Department of Fundamental Pharmaceutical Sciences, „George Emil Palade" University of Medicine, Pharmacy, Science and Technology, Targu Mures, Romania

${ }^{5}$ Emergency Institute for Cardiovascular Diseases and Transplantation, Targu Mures, Romania
Contact address:

Zoltán Preg, MD

Department of Cardiovascular Rehabilitation, Emergency Clinical

County Hospital, Targu Mures, Romania.

E-mail: preg_zoltan@hotmail.com 


\section{INTRODUCTION}

Dementia is decribed as continuous decline of cognitive function and it is recognized as a major contributor to disability and dependency amongst the elderly. There is an alarmingly rapid increase in the number of people living with dementia across the world. In 2015 dementia affected 47 million people, $63 \%$ coming from low-and middle income countries'. By 2050 a near exponential rise is expected reaching a total number of I35 million people, attributable to aging and growth of population'. Although age is undoubtedly the most important risk factor for cognitive decline, dementia is not a normal part of ageing. The most frequently encountered forms of dementia are Alzheimer disease (AD) representing $70 \%$ of all cases and vascular dementia $(\mathrm{VaD})$ in $15 \%$. Almost half a century ago researchers found a connection between heart disease and altering cognitive function and named it ,,cardiogenic dementia" 2 . Despite this, insight to this matter has been ignored until the early 1990s. Since than, more and more studies focused on understanding the link between cardiovascular risk factors and cognitive decline.

Currently there is a considerable amount of scientific evidence supporting that cardiovascular diseases and dementia share potentially modifiable risk factors $^{3}$. Lifestyle related factors like smoking, sedentarism, diet and other major cardiovascular risk factors like hypertension, diabetes mellitus, hypercholesterolemia, obesity are linked to vascular injury as well as neurodegenerative lesions of the brain ${ }^{3-5}$. These changes lead to worsening cognitive abilities and they can vary from subclinical forms to major neurocognitive disorders called dementia. Subtle modifications in daily functioning or behavior reflecting subjective cognitive failure (SCF) or mild cognitive impairment $(\mathrm{MCl})$ are frequently overlooked, or interpreted in context of the normal aging process. At least half of dementia cases are preceded by mild neurocognitive disorders ${ }^{5}$.

Dementia was considered an unpreventable affection for a long time. Lately, progresses have been made in this field. Based on a modelling exercise, decreasing level of risk by $10 \%$ could lower the overall prevalence of dementia by $8.3 \%$. Furthermore, it is likely to prevent more than one third of dementia cases adopting a life-course approach, which takes into account the additive and cummulative effects of modifiable risk factos over the lifespan'. However, only identifying and targeting risk factors in early to midlife seems to have such on impact or at least delay or slow cognitive im- pairment and dementia. As currently dementia has no cure, evaluating and modifying dementia risk factors is a huge challenge in lowering dementia prevalence.

In this report we summarize the latest findings on six modifiable vascular risk factors connected to cognitive compromise and dementia: arterial hypertension, diabetes mellitus, smoking, obesity, hypercholesterolemia and physical exercise. Additionally, we synthethise currently available evidence related to interventions on these risk factors proven to be effective in influencing cognitive health.

\section{Hypertension}

There is mounting evidence that hypertension is a major contributor to cognitive decline as well as dementia. The association is complex, and variable through the life-span, and still unsettled.

Brain is one of the most vulnerable target organ affected by hypertension. Long term effect of elevated pressures are silent lesions of the brain, ischaemic and haemorrhagic stroke. Mechanisms through which hypertension becomes a risk factor for cognitive decline are complex. Microvascular and macrovascular changes are involved, resulting in functional and structural cerebrovascular modifications. The deleterious effects of higher pressures result in endothelial dysfunction and lesions secondary to mechanical stress, increased vascular resistance and stiffness, reduced vascular lumen caused by vascular smooth muscle hypertrophy. Ultimately, these modifications decrease cerebral blood flow, alter cerebral autoregulation, predispose to accumulation of beta amyloid, thus compromising the metabolism and structure of the brain. Vascular changes localized at the resistance vessels are known as cerebral small vesssel disease, and can be silent. Markers of cerebral small vessel disease are present in $35 \%$ of hypertensive patients and they can be detected by magnetic resonance imaging $(M R I)^{5}$. These are white matter hyperintensities (WMH), cerebral microbleeds (CMB), lacunar infarcts (LI) and enlarged perivascular spaces (EPS)5. Studies focusing on these lesions concluded that all four markers are related to high blood pressure and cognitive impairment. Additionally results of a recent systematic review showed an association between the stiffening of the large arteries, microvascular brain disease and poor cognitive performance.

Evidence on the association between blood pressure and cognition come mostly from observational studies. We learned from epidemiological cross-sectional and longitudinal surveys, that hypertension is 
one of the most important and most widely explored congitive decline and dementia risk factor, although controversies still exist. On one hand, most of the researchers agree that cognitive impairment and dementia are more frequent in patients with hypertension ${ }^{5,7}$, while others found higher prevalence rate connected to hypotension. A $U$-shaped relationship between hypertension and cognitive abilities has also been described $^{8}$. On the other hand, there is strong evidence that high blood pressure starting in mid-life, during the forth and fifth decade, especially if not treated, favours in later life both vascular dementia and AD. In contrast the promoting role of late-life hypertension on cognitive decline is less clear ${ }^{8}$. In later life and in very old age both deleterious and beneficial effects of hypertension on cognitive abilities were demonstrated $^{8}$. Severe atherosclerosis in the very elderly, as well as episodic or sustained hypotension and, possibly, excessive treatment of hypertension, may induce cerebral hypoperfusion, ischemia, and hypoxia in this age group 5 . For example in the Rotterdam Study lower diastolic blood pressure in individuals older than 80 years was linked to higher risk of dementia'. In the Baltimore Longitudinal Study of Aging, both hypertension and hypotension have been shown to be associated with poorer performance on tests of executive function in older individuals ${ }^{10}$.

However, evidence with respect to the cognitive domains affected by hypertension are consistent, pointing specifically to executive dsyfunction and slower speed in processing information having an impact on making decisions in daily activities ${ }^{8}$, regardless of age.

As stated, hypertension is a potentially modifiable risk factor of cognitive decline. Whether blood pressure lowering treatment could also lower the risk of cognitive disruption or at least defer dementia time of onset, have been evaluated in randomized clinical trials (RCTs). They resulted in inconclusive evidence. Several studies, like Progress, SYST-EUR, HOPE found positive association between antihypertensive therapy and cognitive decline as well as dementia ${ }^{5}$. On the contrary, no such link was found in other trials like MRC, SHEP, SCOPE, and HYVET-COG ${ }^{5,8,10}$. A network meta-analysis of RCTs which analyzed the effect of different antihypertensive drugs on cognitive function concluded that antihypertensive agents are beneficial in dementia and cognitive impairment risk reduction ${ }^{8}$. By contrast, a recent meta-analysis of prospective cohort studies reported that blood pressure lowering intervention does not influence cognitive impairment, cognitive decline or Alzheimer's disease, although it significantly reduces the risk of dementia'".

\section{Diabetes mellitus}

Hyperglycaemia is one of the modifiable cardiovascular risk factors. Dysglycaemia and type 2 diabetes (T2DM) were demonstrated to be linked to cognitive decline in large epidemiological studies ${ }^{12-14}$. This relation is stronger with age progression, but was found to be present at any stage of life, not only in older patients, as it was shown in the meta-analyses of Pelimanni and Jehkonen ${ }^{15}$, and even present among type I or type 2 diabetes children and adolescents. Recent studies concluded that diabetes related complications (like albuminuria in nephropathy, visual impairment in retinopathy or hear loss) are also associated with increased risk of dementia ${ }^{16,17}$. The causes of cognitive impairment in diabetes are diverse. Most of the patients have a variety of reasons to have neurological impairment. High blood glucose levels are related to a greater cognitive decay, as it is expected ${ }^{18}$.

However, hypoglycaemia, in insulin or sulphonylurea treated patients, is also associated with alteration of cognitive function. The effect of low blood sugar will depend on its degree, duration and recurrence. In acute hypoglycaemia attention-concentration, processing speed are altered. Recurrent episodes of low blood sugar will cause memory decline and impaired problem solving ${ }^{19}$. In a cohort of the Nurse Health Study higher level of $C$ peptide predicted a worse cognitive decline after 10 years of follow up ${ }^{20}$.

Brain insulin resistance is parallel with systemic insulin resistance. The diminished intracellular insulin effect will result in weakened memory function, cell proliferation and enhanced cell apoptosis. There are studies suggesting that insulin resistance, and subsequent hyperinsulinaemia are involved in the increased concentration of amyloid- $\beta$ in the brain ${ }^{21}$.

The occurrence of one or more APOE epsilon ${ }^{4}$ alleles, frequently present in metabolic syndrome, is associated with a lower cognitive performance in patients with diabetes, even if adjusted for age, education, sex, race/ethnicity and APOE genotype ${ }^{22}$.

Diabetes related accelerated atherosclerosis and microangiopathy promote vascular brain damage, not only through hypoxic neuronal damage, but also via neurovascular uncoupling. Hyperglycaemia causes endothelial dysfunction, accumulation of AGE molecules, and increases the production of reactive oxygen species which will finally result in reduced local blood flow. 
The chronic inflammation present in T2DM, accompanying insulin resistance is linked to beta-amyloid deposition in the brain, the cornerstone pathological change in AD. Epidemiological studies have long demonstrated that $A D$ is more frequent in T2DM, due to the common cause of insulin resistance ${ }^{23}$. However in patients with diabetes clinical dementia is not equal with $A D$ diagnoses, because cerebral autopsy demonstrated in these patients a frequent association of cerebral infarcts with Alzheimer type neuropathological changes ${ }^{23,24}$.

The best brain imaging techniques in diabetes, which might help in identifying the cause of cognitive decline, are amyloid PET scan, SPECT, angioMRI, diffusion tensor imaging (DTI) ${ }^{25}$.

Regarding the type of cognitive functions affected, the largest differences in performance between patients with diabetes and control subjects are found in information processing speed, attention-concentration, executive functions and working memory. However, there are differences between cognitive impairment in type $I$ and type 2 diabetes. In the first slowing of information processing, impaired problem solving and lower psychomotor efficiency were largely observed, while in the latter impaired memory, executive function deficit, and depression were more evident ${ }^{26}$. Because of the metabolic memory of cells, caused by epigenetic modifications at mitochondrial level due to hyperglycaemia, improving glycaemic control will not necessarily improve cognitive outcomes. Early intervention on blood sugar may prevent or slower intellectual decline. Knowing the role of insulin resistance in the increased risk for dementia, early weight control and healthy diet are an effective tool in preserving the intellectual capacity of the individual. Regular consumption of fruits and vegetables is also diminishing the risk of dementia ${ }^{27}$. It is also demonstrated, that higher fish consumption may be capable of preserving memory ${ }^{28}$.

Prevention of hypoglycaemia in type I and type 2 diabetes is crucial for preserving the cognitive functions. In the former, frequent blood glucose monitoring, and using continuous glucose monitoring systems might be helpful. In T2DM newer glucose lowering drug classes and avoiding sulphonyureas may diminish the possibility of low blood sugar level.

There is emerging evidence that incretin effect based glucose-lowering therapies (DPP4 inhibitors and GLPI analogues) might slower the cognitive decline in patients with diabetes, and may improve cognitive recovery after stroke ${ }^{29}$.
Modifiable cardiovascular risk factors and cognitive aging

Hyperglycaemia and hypoglycaemia will contribute to cognitive impairment at any age, both in type I and type 2 diabetes. Only early and aggressive interventions on hyperglycaemia will have beneficial effect on cognitive decline and dementia prevention. The risk of hypoglycaemia must be addressed in the treatment of diabetes. Using the incretin based therapies in diabetes might bring an additional beneficial effect regarding the cognitive decline ${ }^{29}$.

\section{Smoking}

The role of smoking in the development of cognitive impairment and dementia is now clear. A metaanalysis of 17 longitudinal studies assessing the effect of current smoking on the development of dementia involving 937.392 subjects for all-cause dementia, 907.077 subjects for AD respectively 882.548 subjects for vascular dementia found that current smokers had significantly increased risk of all-cause dementia (RR I.30, 95\% Cl I.18-I.45), AD (RR I.40, 95\% Cl I.I3-I.73) and vascular dementia (RR I.38, 95\% Cl I.I5-I.66) compared to never smokers ${ }^{30}$. There is a linear dose-response relationship between the amount of cigarettes smoked per day and the relative risk of dementia ${ }^{30}$. The most likely mechanism underlying the association between smoking and $A D$ is vascular disease. Smoking contributes to a variety of subclinical and clinical vascular disorders including atherosclerosis and stroke (symptomatic or asymptomatic), which, in turn, could lead to increased risk of dementia. Tobacco smoke also contains hundreds of neurotoxins which could contribute to cognitive decline through oxidative stress, inflammatory processes, or direct toxicity mechanisms ${ }^{31}$. Second hand smoking is also considered as a risk factor for cognitive decline, the higher the exposure, the higher the risk of cognitive decline ${ }^{32}$.

Quitting smoking is beneficial for the purpose of preventing the development of cognitive decline and dementia. The Whitehall II Cohort study found that in ex-smokers, with at least a 10 -year cessation, there were no adverse effects of their past smoking on cognitive decline ${ }^{33}$. Other long-term cohort studies also suggest that the risk for dementia in former smokers (after several years of not smoking) approaches that of never smokers ${ }^{30}$.

Prevention of dementia is a good argument for smoking cessation, because more patients are concerned about the risk of cognitive decline than other smoking related complications. 


\section{Obesity}

Epidemiological studies addressing the risk of obesity and dementia have reported equivocal results. Inconsistencies mainly appear with regard to the age at which the presence of obesity was assessed ${ }^{34}$.

Most of the studies agree that midlife obesity is a risk factor for dementia ${ }^{35}$. Results from the Whitehall II study of more than 10.000 patients with repeated BMI assessments for more than 28 years show that obesity (BMI $\geq 30 \mathrm{~kg} / \mathrm{m}^{2}$ ) at 50 years is a risk factor for dementia ${ }^{36}$. This association was greatly attenuated when BMI was assessed at ages 60 and 70 years $^{36}$. This study demonstrated that the association between obesity and dementia is modified by age at obesity measurement, such that midlife obesity is a risk factor for dementia but BMI begins to decline in those with dementia in the years before diagnosis ${ }^{36}$. The study suggests that patients who develop dementia have different BMI trajectories than patients who will not develop dementia ${ }^{36}$.

The exact mechanisms explaining the increased risk of dementia associated with obesity are not fully understood. Obesity in midlife and at older ages is associated with brain atrophy ${ }^{37}$. There is also evidence suggesting that a variant of the fat mass and obesityassociated gene affects brain structure, causing deficits in the frontal and occipital lobes ${ }^{38}$. Obesity is also likely to influence cognition through its impact on other cardiovascular risk factors, and the role of adipocyte hormones and cytokines is under investigation. Genome-wide association studies, showed genetic risk variants that could influence vascular and inflammatory pathways to be associated with dementia ${ }^{39}$.

It is not clearly demonstrated that weight loss in midlife could prevent cognitive decline or dementia, but several studies suggest that the better the cardiovascular risk profile, the lower the risk of cognitive decline ${ }^{40,41}$.

\section{Hypercholesterolemia}

Association between cholesterolemia and cognitive decline has been investigated by several studies and the outcome is controversial. There are large population-based prospective studies such as the NEDICES study performed in Spain showing that elderly subjects with hypercholesterolemia presented significantly slower cognitive decline compared to those with normal cholesterol levels during a 3-year follow-up, MMSE test being used for assessment of cognitive functions ${ }^{42}$. Researchers investigating the hippocampus found in a study performed in China that type 2 diabetic pati- ents with poorly controlled cholesterolemia showed impairment in attention and executive function, and decreasing the LDL-cholesterol/HDL-cholesterol ratio can be protective against cognitive decline ${ }^{43}$. Another community-based study on elderly Chinese population showed that higher serum total and LDLcholesterol were significantly associated with greater cognitive impairment based on the MMSE test score ${ }^{44}$. The REGARDS study conducted in the USA showed no association between lower LDL-cholesterol levels and cognitive dysfunction in the studied population ${ }^{45}$.

Other studies investigated the effect of cholesterol lowering medication on cognitive functions. Researchers in the USA found that statins have a beneficial effect on cognitive functions, subjects under this kind of treatment showing less impairment in their cognitive functions ${ }^{46}$.

In a study performed on Irish population Montreal Cognitive Assessment test was used to evaluate cognitive performance and no relationship was found between use of cardiovascular medication (antihypertensive, antithrombotic, lipid-modifying drugs) and cognitive function ${ }^{47}$. The controversial outcome of different studies suggests that statins may have double effect through independent mechanisms. Statins might have a contribution to reversible cognitive dysfunction, and in the same time they are drugs useful in prevention of dementia. The negative impact of statins on cognitive function might be due to lowering cholesterol level in the brain, especially in case of high doses and genetic vulnerability. On the other hand, statins have protective effect against dementia by prevention of stroke and lowering the incidence of microvascular infarction in the brain, and by reducing neuroinflammation ${ }^{48}$.

In spite of all the controversies, there is consistent evidence supporting the role of atherosclerosis in the development of dementia and cognitive impairment ${ }^{49}$, so minimalizing cardiovascular risk factors and reducing the development of atheromas is essential for maintaining proper brain function of the patients.

\section{Physical exercise}

Sedentary lifestyle is a negative attribute of modern lifestyle and a well-known cardiovascular risk factor. There is many convincing data supporting that physical exercise (PE) as a healthy behavior has positive effects not only on general and cardiovascular health, but also on brain structure and function. Opposite to this sedentary behavior may lead to worsening of both cardiovascular health and cognitive abilities. Accordin- 
gly, a recent work of Siddarth et al. showed that sedentary lifestyle was connected to less temporal lobe thickness which might have an influence on long-term memory $\operatorname{loss}^{50}$. An analysis of population-based data made by Norton and collaborators concluded that the population-attributable risk of low PE for dementia is $20.3 \%$ in Europe $(95 \% \mathrm{Cl} \text { 5.6-35.6) })^{51}$.

Physical exercise has been proven to have protective effects on neuro-degenerative processes through several mechanisms. These include morphological changes like increasing of grey matter volume in the frontal and hippocampal regions, and functional modifications like increase in neutrophic factors, growth factors, testosterone, level of serotonin, beta-endorphins, cerebral blood flow and decreased insulin resistance ${ }^{52}$. Recently, epigenetic mechanisms, increased gene expression mediated by PE have also been evoked ${ }^{52}$. All these changes reduce beta amyloid accumulation in the brain, enhance neurogenesis in the hippocampal area, neuroplasticity and decrease neurodegeneration ${ }^{52}$. In addition, PE is also related to higher cognitive reserve through promoting more effective connections between existing neurons ${ }^{52}$. Finally, combined with the positive psychological effects of $\mathrm{PE}$, like increased selfconfidence, decreased depression and anxiety, cognitive performances are improved ${ }^{52}$. Furthermore, a wealth of evidence points out that PE improves quality of life, prevents age-related cognitive worsening and lowers the risk of dementia. Indeed, longitudinal and cross sectional studies have consistently demonstrated that individuals with regular physical activity have higher cognitive function and less likely to develop any form of dementia including Alzheimer disease ${ }^{52}$. In addition, randomized intervention trials demonstrated a positive influence when investigating the impact of aerobic PE on cognitive abilities and/or cognitive decline $^{53}$. Beneficial effects of PE on cognitive performance appear regardless of age. However, type and duration of exercise may interfere with the impact on brain health. Moderately intense chronic aerobic exercise has important influence on memory and executive functions while high intensity PE has positive effect on processing speed. Effects of acute aerobic exercise on cognitive improvement have been also demonstrated, although these effects are less small ${ }^{54}$. According to a meta-analysis combination of aerobic and resistance exercise might have the greatest results on improving cognitive abilities ${ }^{55}$. With respect to PE duration scientists agree that weekly 150 minutes of moderate to intense exercise should be completed to reach bene- ficial effects on cognition. It has also been stated, that people need to commit to regular PE lifelong ${ }^{56}$.

\section{Conclusions}

This report explored current knowledge regarding the effect of modifiable cardiovascular risk factors on cognitive function. In light of the presented information we conclude there is an overlapping between known vascular risk factors and risk factors for dementia. Association of risk factors with cognitive decline is not yet fully clarifyed, yet it is stated that potentially modifiable risk factors are responsible for one third of $A D^{51}$. We believe, there is enough evidence to support the fact that mid-life cardiovascular risk factors can promote cognitive impairment and/or dementia later in life. Hypertension, diabetes mellitus, obesity, hypercholesterolemia, smoking and sedentarism are promising intervention targets for preventing or delaying dementia. They should be monitored and treated aggressively as soon as possible. Finally, we consider that in the presence of vascular risk factors routine cognitive screening and follow-up of cognitive worsening are recommended.

\section{Conflict of interest: none declared.}

\section{References}

I. Livingston G, Sommerlad A, Orgeta V, Costafreda SG, Huntley J, Ames D, Ballard C, Banerjee S, Burns A, Cohen-Mansfield J, Cooper C, Fox N, Gitlin LN, Howard R, Kales HC, Larson EB, Ritchie K, Rockwood K, Sampson EL, Samus Q, Schneider LS, Selbaek G, Teri L, Mukadam N. Dementia prevention, intervention, and care. Lancet 20I7;390: 2673-2734

2. Mccarthy ST, Woolner L, Roseberg GA, York-Haalnad K. Cardiogenic dementia. Lancet 1981;318: II7I

3. Lourenco J, Serrano A, Santos-Silva A, Gomes M, Afonso C, Freitas P, Paul C, Costa E. Cardiovascular risk factors are correlated with low cognitive function among older adults across Europe based on the SHARE database. Aging and Disease 2018;9: 90-10I

4. Baumgart M, Snyder HM, Carrillo MC, Fazio S, Kim H, Johns H. Summary of the evidence on modifiable risk factors for cognitive decline and dementia: A population-based perspective. Alzheimer's \& Dementia 20I5; I I: 7I8-726

5. Coca A. Hypertension and Brain Damage. Updates in Hypertension and Cardiovascular Protection. Eds G Mancia, E Agabiti et al. Springer International Publishing Switzerland, 2016, 13-47, 197-208

6. Singer J, Trollor JN, Baune BT, Sachdev PS, Smith E. Arterial stiffness, the brain and cognition: a systematic review. Ageing Res Rev 2014;15: 16-27

7. Muela HCS, Costa-Hong VA, Yassuda MS, Moraes NC, Memoria CM, Machado MF, Macedo TA, Shu EBS, Massaro AR, Nitrini R, Mansur AJ, Bortolotto LA. Hypertension severity is associated with impaired cognitive performance. J Am Heart Assoc 2017;6: I-I I

8. Walker KA, Power MC, Gottesman RF. Defining the relationship between hypertension, cognitive decline, and dementia: a review. Curr Hypertens Rep 2017;19: I-27

9. Verghese J, Lipton RB, Hall CB, Kuslansky G, Katz MJ. Low blood pressure and the risk of dementia in very old individuals. Neurology 2003;6I: I667-I672

10. ladecola C, Yaffe K, Biller J, Bratzke LC, Faraci FM, Gorelick PB, Gulati M, Kamel H, Knopman DS, Launer LJ, Saczynski JS, Seshadri S, 
Zeki Al Hazzouri A. Impact of hypertension on cognitive function: A scientific statement from the American Heart Association. Hypertension 2016;68: 67-94

II. Xu G, Bai F, Lin X, Wang Q, Wu Q, Sun S, Jiang C, Liang Q, Gao B. Association between antihypertensive drug use and the incidence of cognitive decline and dementia: A meta-analysis of prospective cohort studies. Biomed Res Int 2017;20 I7: I-I I

12. Van Den Berg E, De Craen AJM, Biessels GJ, Gussekloo J, Westendorp RGJ. The impact of diabetes mellitus on cognitive decline in the oldest of the old: A prospective population-based study. Diabetologia 2006;49: 2015-2023

13. Luchsinger JA. Diabetes, related conditions, and dementia. J Neurol Sci 2010;299: 35-38

14. Profenno LA, Porsteinsson AP, Faraone SV. Meta-Analysis of Alzheimer's disease risk with obesity, diabetes, and related disorders. Biol Psychiatry 2010;67: 505-5I2

15. Pelimanni E, Jehkonen M. Type 2 diabetes and cognitive functions in middle age: A meta-analysis. J Int Neuropsychol Soc 2019;25: 215229

16. Bruce DG, Davis WA, Starkstein SE, Davis TM. Mid-life predictors of cognitive impairment and dementia in type 2 diabetes mellitus: The fremantle diabetes study. J Alzheimer's Dis 2014;42: 63-70

17. Exalto LG, Biessels GJ, Karter AJ, Huang ES, Katon WJ, Minkoff JR, Whitmer RA. Risk score for prediction of 10 year dementia risk in individuals with type 2 diabetes: a cohort study. Lancet Diabetes Endocrinol 2015; I: 183-190

18. Yaffe K, Falvey C, Hamilton N, Schwartz AV, Simonsick EM, Satterfield S, Cauley J, Rosano C, Launer L, Strotmeyer ES, Harris T. Diabetes, glucose control and 9 year cognitive decline among nondemented older adults. Arch Neurol 2012;69: I I70-II75

19. Warren RE, Frier BM. Hypoglycaemia and cognitive function. Diabetes Obes Metab 2005;7: 493-503

20. Okereke OI, Pollak MN, Hu FB, Hankinson SE, Selkoe DJ, Grodstein F. Plasma C-peptide levels and rates of cognitive decline in older, community-dwelling women without diabetes. Psychoneuroendocrinology 2008;33: 455-46।

2I. Planel E, Tatebayashi Y, Miyasaka T, Liu L, Wang L, Herman M, Yu WH, Luchsinger JA, Wadzinski B, Duff KE, Takashima A. Insulin dysfunction induces in vivo tau hyperphosphorylation through distinct mechanisms. J Neurosci 2007;27: I3635-13648

22. Dore GA, Elias MF, Robbins MA, Elias PK, Nagy Z. Presence of the APOE $\varepsilon 4$ allele modifies the relationship between type 2 diabetes and cognitive performance: The Maine-Syracuse Study. Diabetologia 2009;52: 255।-2560

23. Vagelatos NT, Eslick GD. Type 2 diabetes as a risk factor for Alzheimer's disease: The confounders, interactions, and neuropathology associated with this relationship. Epidemiol Rev 20।3;35: I52-I60

24. Li J, Cesari M, Liu F, Dong B, Vellas B. Effects of diabetes mellitus on cognitive decline in patients with Alzheimer disease: A systematic review. Can J Diabetes 2017;41: I|4-119

25. Biessels GJ, Despa F. Cognitive decline and dementia in diabetes mellitus: mechanisms and clinical implications. Nat Re Endocrinol 2018; |4: 59|-604

26. Cox DJ, Kovatchev BP, Gonder-Frederick LA, Summers KH, McCall A, Grimm KJ, Clarke WL. Relationships between hyperglycemia and cognitive performance among adults with type I and type 2 diabetes. Diabetes Care 2005;28: 71-77

27. Gomez-Pinilla F. Brain foods: the effects of nutrients on brain function. Nat Rev Neurosci 2008;9: 568-578

28. Qin B, Plassman BL, Edwards LJ, Popkin BM, Adair LS, Mendez MA. Fish intake is associated with slower cognitive decline in Chinese older adults: a Longitudinal Study from the China Health and Nutrition Survey. Circulation 2014; 129: 185-185

29. Angelopoulou E, Piperi C. DPP-4 inhibitors: a promising therapeutic approach against Alzheimer's disease. Ann Transl Med 2018;6: 255255

30. Zhong G, Wang Y, Zhang Y, Guo JJ, Zhao Y. Smoking is associated with an increased risk of dementia: A meta-analysis of prospective cohort studies with investigation of potential effect modifiers. PLOS ONE 2015;10: 1-23
31. Peters R, Poulter R, Warner J, Beckett N, Burch L, Bulpitt C. Smoking, dementia and cognitive decline in the elderly, a systematic review. BMC Geriatrics 2008;8: 36

32. Chen R, Wilson K, Chen Y, Zhang D, Qin X, He M, et al. Association between environmental tobacco smoke exposure and dementia syndromes. Occup Environ Med 2013;70: 63-69

33. Sabia S, Elbaz A, Dugravot A, Head J, Shipley M, Hagger-Johnson G, Kivimaki M, Singh-Manoux A. Impact of Smoking on Cognitive Decline in Early Old Age: The Whitehall II Cohort Study. Arch Gen Psychiatry 2012;69: 627-635

34. Pedditizi E, Peters R, Beckett N. The risk of overweight/obesity in mid-life and late life for the development of dementia: a systematic review and meta-analysis of longitudinal studies. Age Ageing 2016;45: |4-2|

35. Chuang Y-F, An Y, Bilgel M, Wong DF, Troncoso JC, O’Brien RJ, Breitner C, Ferucci L, Resnick SM, Thambisetty M. Midlife Adiposity predicts earlier onset of Alzheimer's dementia, neuropathology and presymptomatic cerebral amyloid accumulation. Mol Psychiatry 2016;2।: 910-915

36. Singh-Manoux A, Dugravot A, Shipley M, Brunner EJ, Elbaz A, Sabia $S$, Kivimaki M. Obesity trajectories and risk of dementia: 28 years of follow-up in the Whitehall II Study. Alzheimers Dement 2018; 14: I78-186

37. Ho AJ, Raji CA, Becker JT, Lopez OL, Kuller LH, Hua X, Lee S, Hibar D, Dinov ID, Stein JL, Jack Jr CR, Weiner MW, Toga AW, Thompson PM. Obesity is linked with lower brain volume in $700 \mathrm{AD}$ and $\mathrm{MCl}$ patients. Neurobiol Aging 2010;31: 1326-1339

38. Ho AJ, Stein JL, Hua X, Lee S, Hibar DP, Leow AD, Dinov ID, Toga AW, Saykin AJ, Shen L, Foroud T, Pankratz N, Huentelman M, Craig DW, Gerber JD, Allen AN, Corneveaux JJ, Stephan DA, DeCarli CS, DeChairo BM, Potkin SG, Jack Jr CR, Weiner MW, Raji CA Lopez OL, Becker JT, Carmichael OT, Thompson PM. A commonly carried allele of the obesity-related FTO gene is associated with reduced brain volume in the healthy elderly. Proc Natl Acad Sci USA 2010;107: 8404-9

39. Tosto G, Reitz C. Genome-wide association studies in Alzheimer's disease: A review. Curr Neurol Neurosci Rep 2013; I3: 38 I

40. Samieri C, Perier MC, Gaye B, Proust-Lima C, Helmer C, Dartigues JF, Berr C, Tzourio C, Empana JP. Association of cardiovascular health level in older age with cognitive decline and incident dementia. JAMA 2018;320: 657-64

41. Wagner M, Helmer C, Tzourio C, Berr C, Proust-Lima C, Samieri C. Evaluation of the concurrent trajectories of cardiometabolic risk factors in the 14 years before dementia. JAMA Psychiatry 2018;75: 1033-42

42. Benito-Leon J, Vega-Quiroga S, Villarejo-Galende A, Bermejo-Pareja $\mathrm{F}$. Hypercholesterolemia in elders is associated with slower cognitive decline: A prospective, population-based study (NEDICES). J Neurol Sci 2015;350: 69-74

43. Xia W, Zhang B, Yang Y, Wang P, Yang Y, Wang S. Poorly controlled cholesterol is associated with cognitive impairment in T2DM: A resting-state fMRI study. Lipids Health Dis 2015;14: I-10

44. Ma C, Yin Z, Zhu P, Luo J, Shi X, Gao X. Blood cholesterol in latelife and cognitive decline: A longitudinal study of the Chinese elderly. Mol Neurodegener 2017;12: 1-9

45. Mefford MT, Rosenson RS, Cushman M, Farkouh ME, McClure LA Wadley VG, Irvin MR, Bittner V, Safford MM, Somaratne R, Monda KL, Muntner P, Levitan EB. PCSK9 variants, low-density lipoprotein cholesterol, and neurocognitive impairment. Circulation 2017;137: 1260- 1269

46. Smith KB, Kang P, Sabbagh MN. The effect of statins on rate of cognitive decline in mild cognitive impairment. Alzheimer's Dement Transl Res Clin Interv 2017; 3: 149-156

47. Rohde D, Hickey A, Williams D, Bennett K. Cognitive impairment and cardiovascular medication use: Results from wave I of The Irish Longitudinal Study on Ageing. Cardiovasc Ther 2017;35: I-10

48. Schultz BG, Patten, DK, Berlau DJ. The role of statins in both cognitive impairment and protection against dementia: $A$ tale of two mechanisms. TransI Neurodegener 2018;7: I-II 
49. Bos D, Vernooij MW, de Bruijn RFAG, Koudstaal PJ, Hofman A, Franco $\mathrm{OH}$, van der Lugt $\mathrm{A}$, Ikram MA. Atherosclerotic calcification is related to a higher risk of dementia and cognitive decline. Alzheimer's Dement 2015; I I: 639-647

50. Siddarth P, Burggren AC, Eyre HA, Small GW, Merrill DA. Sedentary behavior associated with reduced medial temporal lobe thickness in middle-aged and older adults. PLoS One 2018;13: I-I3

5I. Norton S, Matthews FE, Barnes DE, Yaffe K, Brayne C. Potential for primary prevention of Alzheimer's disease: an analysis of populationbased data. Lancet Neurol 20 I4;13: 788-794

52. Middleton LE, Yaffe K. Targets for the prevention of dementia. J Alzheimer's Dis 2010;20: 915-924

53. Brown BM, Peiffer JJ, Martins RN. Multiple effects of physical activity
Modifiable cardiovascular risk factors and cognitive aging

on molecular and cognitive signs of brain aging: Can exercise slow neurodegeneration and delay Alzheimer's disease? Mol Psychiatry 2013;18: 864-874

54. Mandolesi L, Polverino A, Montuori S, Foti F, Ferraioli G, Sorrentino P, Sorrentino G. Effects of physical exercise on cognitive functioning and wellbeing: Biological and psychological benefits. Front Psychol 2018;9: I-II

55. Colcombe S, Kramer AF. Fitness effects on the cognitive function of older adults. Psychol Sci 2003; 14: 125-130

56. Vancampfort D, Stubbs B, Lara E, Vandenbulcke M, Swinnen N, Koyanagi $A$. Mild cognitive impairment and physical activity in the general population: Findings from six low- and middle-income countries. Exp Gerontol 2017;100: 100-105. 